\title{
Non-independent speed control for dual-PMSM drives using a single three-leg VSI
}

\author{
Jurifa Mat Lazi ${ }^{1}$, Zulkifilie Ibrahim ${ }^{2}$, Md Hairul Nizam Talib ${ }^{3}$, Auzani Jidin ${ }^{4}$, \\ Ahmad Shukri Abu Hasim ${ }^{5}$ \\ ${ }^{1,2,3,4}$ Departement of Industrial Power, Faculty of Electrical Engineering, Universiti Teknikal Malaysia Melaka \\ ${ }^{5}$ Department of Electrical Engineering, Universiti Pertahanan Nasional Malaysia
}

\begin{tabular}{l} 
Article Info \\
\hline Article history: \\
Received Jun 1, 2020 \\
Revised Aug 1, 2020 \\
Accepted Aug 15, 2020 \\
\hline
\end{tabular}

Keywords:

Dual-PMSM

Non-Independent

Speed control

Three-Leg VSI

\begin{abstract}
The objective of this article is to analyze the performances of non-independent speed control of dual-pmsm (permanent magnet synchronize motor) drives by a single three-leg voltage source inverter (VSI) using control of mean and differential torque technique. In general, there are two types of control strategies for dual-motor drives. One is master-slave technique and another one is mean control technique. For mean control technique, this study chooses mean and differential approach for the motors parameters and using average value for the voltage space vector. The advantages of dual-motor drives fed by a single inverter topology are, it can decrease the size and cost compared to the dual-motor drives which used by individual inverter, either in industrial or in traction applications. However, by using a single three-phase inverter, the topology only restricted for the same operating conditions which are at the same speed, same parameters and same direction. The dual-motors are dependent (non-independent) on the other motor. It is can only be tested on different load operation. The analysis is focuses on speed and load variation for dual-PMSM drives considering the forward and reverse operations of the motor. This simulation model is modelled using MATLAB-Simulink.
\end{abstract}

Copyright $@ 2020$ Institute of Advanced Engineering and Science. All rights reserved.

\section{Corresponding Author:}

Jurifa Mat Lazi,

Faculty of Electrical Engineering, Universiti Teknikal Malaysia Melaka,

Hang Tuah Jaya, 76100 Durian Tunggal, Melaka Malaysia.

Email: jurifa@utem.edu.my

\section{INTRODUCTION}

Dual-Motor Systems is broadly used in industry today especially for high power, electric vehicles and traction power application [1-25]. This system makes the mechanism and operating system of high power applications to be increased. In other hand, the numbers of power switches are increased which costly and bulky. For that reason, single inverter for the Dual-Motor system is proposed to overcome the problems. There are two types of speed control for dual-motor drives which are master-slave and mean control techniques. For master-slave technique, one of the motor is choosen as the master and the other one as the slave. Only master motor will be controlled. Usually, the highest load motor will selected as the master motor, and the other one motor will be set as slave motor. For this topology, the operating conditions are restricted to same values such as same speed, same parameters and the same direction [1-10]. The only advantage of this technique is, only one set of sensor is required for the master motor and the slave motor will be not controlled.

While in mean control technique, there are few techniques being applied by the researcher [11-[2]. The advantage of this technique is, both motors can be controlled using single inverter, but the responses having high ripple, high overshoot, and long recovery time. In [11] uses mean or averaging technique for parameters of the motors and the voltage space vector. But, the article only presents the variation of speed without load disturbance. Other that Wang, Mohktari at.al [12], uses the same averaging technique but using 
direct torque control (DTC) for dual-motor drives. Nonetheless, this technique shows insignificant responses if the parameters are not similar.

On the other hand, [13-16], use mean and differential torque technique for induction motor (IM). This technique employs the stator current vector compared to the average of rotor current vector, so that the required mean torque and differential torque can be achieved. The mean and differential torque technique is introduced to estimate the disagreement between the mean and differential torque values for currents and torques in the case of unbalance load condition. The researchers prove that this technique presents better results for dualPMSM drives compared to averaging technique. Various techniques for controlling dual-motor drives fed by single inverter that employ three-leg are elaborated. This current study chooses this mean and differential control technique for dual-PMSM drives performances. However, this methodology is restricted only for the same operating conditions which are at the same speed, same parameters and same direction. It is only be operated on different load in the case of permanent magnet synchronous motor.

\section{MODELING FOR DUAL-PMSM DRIVES}

The mathematical equations for PMSM " 1 " in $d q$ reference frame can be written by these equations [17-19].

$$
\begin{aligned}
& v_{d 1}=r_{s 1} i_{d 1}+\frac{d}{d t} \psi_{d 1}-\omega_{e} \psi_{q 1} \\
& v_{q 1}=r_{s 1} i_{q 1}+p \psi_{q 1}+\omega_{e} \psi_{d 1}
\end{aligned}
$$

Where;

$$
\begin{array}{ll}
v_{d}, v_{q} & : \text { voltage of } d q \text { axis } \\
i_{d}, i_{q} & : \text { currents of } d q \text { axis } \\
\omega_{e} & : \text { motor's electrical speed } \\
r_{s} & : \text { stator resistance } \\
\psi_{d}, \psi_{q} & : \text { flux linkages of } d q \text { axis }
\end{array}
$$

The flux linkages $\psi_{d}$ and $\psi_{q}$ can be written in term of stator currents and constant flux linkage $\psi_{m}$ based on rotor permanent magnet as;

$$
\begin{aligned}
& \psi_{d 1}=L_{d 1} i_{d 1}+\psi_{m 1} \\
& \psi_{q 1}=L_{q 1} i_{q 1}
\end{aligned}
$$

Where: $L_{d}, L_{q}$ : inductances of $d q$ axis

By substituting (3) and (4) into (1) and (2) the new equations for stator voltages are written as;

$$
\begin{aligned}
& v_{d 1}=r_{s 1} i_{d 1}+L_{d 1} \frac{d}{d t} i_{d 1}-\omega_{e} L_{q 1} i_{q 1} \\
& v_{q 1}=r_{s 1} i_{q 1}+L_{q 1} \frac{d}{d t} i_{q 1}+\omega_{e} L_{d 1} i_{d 1}+\omega_{e} \psi_{m 1}
\end{aligned}
$$

The electromagnetic torque equations are;

$$
\begin{aligned}
& T_{e m 1}-T_{L 1}=J \frac{d \omega_{r 1}}{d t} \\
& T_{e m 1}=\frac{3}{2} p \times \operatorname{real}\left\{i_{1} \psi_{r 1}\right\}
\end{aligned}
$$


And the instantaneous angular position is;

$$
\omega_{r 1}=\frac{d \theta_{1}}{d t}
$$

The modeling of the motor " 2 " can be derived from (1) to (9) by converting the number " 1 " to " 2 ". By assumptions, motor "1" and motor "2" are equal in all parameters. Meanwhile the Stator current space vector which refering to the stationary phase magnetic axes is determined as;

$$
i_{s}=i_{s} e^{j \phi}
$$

\section{M EAN AND DIFFRENTIAL TORQUE CONTROL TECHNIQUE}

Control of mean and differential torque technique is proposed by [13] to overcome the mismatch between mean and differential torque and current values due to unbalance load as depicted in Figure 1.

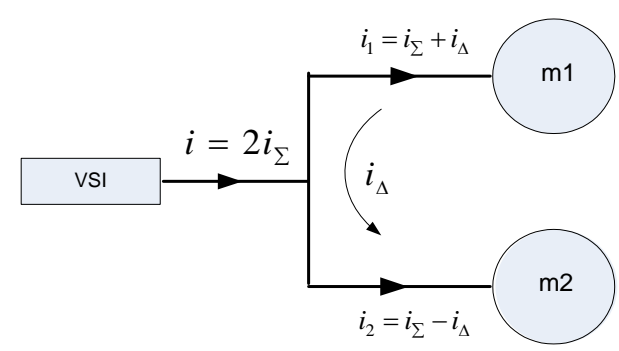

Figure 1. Basic configuration for dual-motor drives fed by single inverter

In [11] introduces the usage of " $\Sigma$ " for mean value and " $\Delta$ " for differential value. The mean and differential expressions for current and the torque space-vectors are given as follows:

$$
\begin{aligned}
& i_{\Sigma}=\frac{i_{1}+i_{2}}{2} ; \quad i_{\Delta}=\frac{i_{1}-i_{2}}{2} \\
& T_{\Sigma}=\frac{T_{1}+T_{2}}{2} ; \quad T_{\Delta}=\frac{T_{1}-T_{2}}{2}
\end{aligned}
$$

Substituting (7) and (8) into (12) yields,

$$
\begin{aligned}
T_{\Sigma} & =\frac{3}{(2)(2)} p \psi_{r}\left[\left(i_{q, 1} \cos \phi+i_{q, 2} \cos (-\phi)\right)+\left(i_{d, 1} \sin \phi+i_{d, 1} \sin (-\phi)\right)\right] \\
& =\frac{3}{2} p \psi_{r}\left[i_{q, \Sigma} \cos \phi+i_{d, \Delta} \sin \phi\right] \\
T_{\Delta} & =\frac{3}{(2)(2)} p \psi_{r}\left[\left(i_{q, 1} \cos \phi-i_{q, 2} \cos (-\phi)\right)+\left(i_{d, 1} \sin \phi-i_{d, 2} \sin (-\phi)\right)\right] \\
& =\frac{3}{2} p \psi_{r}\left[i_{q, \Delta} \cos \phi+i_{d, \Sigma} \sin \phi\right]
\end{aligned}
$$

To improve the steady-state and transient responeses, the speed control can be achieved by carrying out the evaluation of the current reference values $i d_{, \Sigma}^{*}$ and $i q^{*}{ }_{\Sigma}$ as follows;

$$
i_{d, \Sigma}^{*}=\frac{1}{\sin \hat{\phi}}\left[\frac{2}{3 p \psi_{r}} T^{*}{ }_{\Delta}-i_{q, \Delta} \cos \phi\right]
$$




$$
i_{q, \Sigma}^{*}=\frac{1}{\cos \hat{\phi}}\left[\frac{2}{3 p \psi_{r}} T_{\Sigma}^{*}-i_{d, \Delta} \sin \phi\right]
$$

which " $\phi$ " is equal to average rotor position minus of rotor position of $\mathrm{m} 1$ or $\mathrm{m} 2\left(\phi=\theta-\theta_{1}\right.$, or $\left.\phi=\theta-\theta_{2}\right)$

The mean and differential technique is used to control a single-three phase Voltage Source Inverter (VSI) for non-independent speed controlled of dual-PMSM drives called $\mathrm{m} 1$ and $\mathrm{m} 2$. The simulation results based on this technique will be used as the refernced to the proposed drives.

\section{SVPWM FOR DUAL-PMSM DRIVES USING A SINGLE THREE-LEG VSI}

This part, focuses on development of SVPWM for dual-PMSM drives. Figure 2 shows the basic configuration of SVPWM for dual PMSM drives. Firstly, the PI speed controller produces the torque $\mathrm{i}_{\mathrm{q}}$ * current reference, then, two PI current controller will regulate the $\mathrm{i}_{\mathrm{q}} *$ and $\mathrm{i}_{\mathrm{d}} *$ reference currents to produce $\mathrm{d}$ $\mathrm{q}$ reference voltages $\left(\mathrm{V}_{\mathrm{q}} *, \mathrm{~V}_{\mathrm{d}} *\right.$ ). These $\mathrm{d}-\mathrm{q}$ voltages are then transformed to $\alpha-\beta$ reference frame by inverse Park's transformation. Then, using inverse Clark's transformation, $\mathrm{V}_{\alpha}{ }^{*}$ and $\mathrm{V}_{\beta}{ }^{*}$, are converted to three phase voltages, $\mathrm{V}_{\mathrm{a}}, \mathrm{V}_{\mathrm{b}}, \mathrm{V}_{\mathrm{c}}$. These signals are used to generate $\mathrm{SVPWM}$ control signals before they produce threephase stator voltages to drive the PMSM. Since it is dual motor, the average of d-q voltages $\left(\mathrm{V}_{\mathrm{d}, 1} *, \mathrm{~V}_{\mathrm{q}, 1}\right.$ *, $\mathrm{V}_{\mathrm{d}, 2^{*}}, \mathrm{~V}_{\mathrm{q}, 2^{*}}$ ) for both motors are calculated in order to be transformed to three-phase voltages. As a feedback, the three phase current output, need to be transformed back to d-q model by using Clark's and Park's transformations. Then, the actual $d-q$ currents $i_{d}$ and $i_{q}$ will be compared with the references current before tuned again by the current controller.

As mentioned earliear, the SVPWM method using three-leg VSI is not capable to operate in different operating condition except for different load applied. The solution for dual-PMSM drives that can operate at different operating condition is by using five-leg VSI. The next section presents the simulation results for nonindependent speed control for dual-PMSM drives fed by three-leg VSI based on mean and differential control.

\section{RESULTS AND ANALYSIS}

Detailed behavior of dual-PMSM drives with mean and different control technique is studied based on simulation model as shown in Figure 2. The Dual-PMSM drives using mean-differential control technique fed by three-leg VSI is categorized as non-independent speed control. This technique is restricted only for application that operates under the same operating conditions which are at the similar speed, similar parameters and similar direction. This is why, the presentation of the simulation results is slightly different with other simulation and experimental results. The simulation results of forward and reverse operation are combined with the results of load disturbance because the speed responses for $\mathrm{m} 1$ and $\mathrm{m} 2$ will be the same.

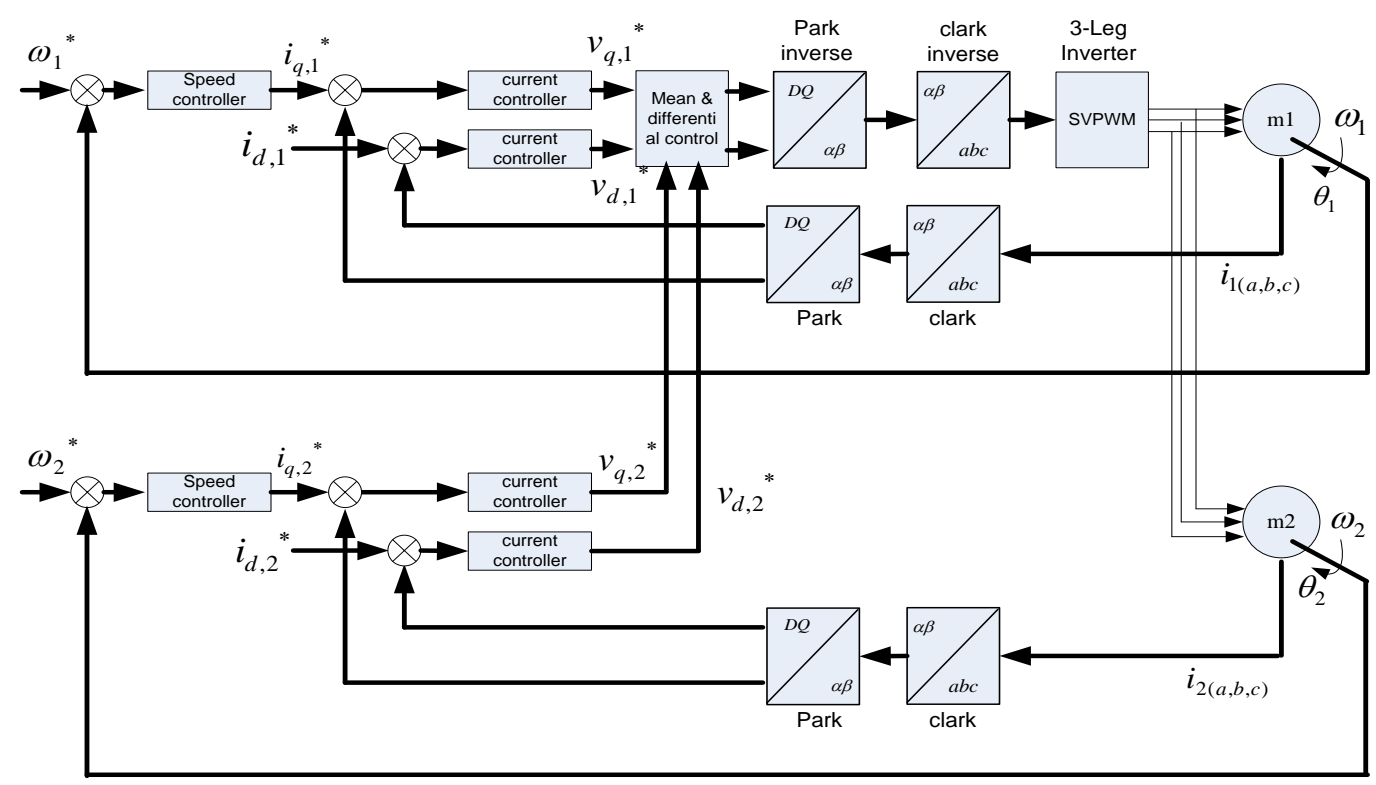

Figure 2. SVPWM configuration for dual-PMSM based on mean and differential torque 


\section{Forward and reverse Operation}

The dual-motor drives is simulated using MATLAB/Simulink under forward and reverse operations for wide ranges of speed. The relevant parameters of the motors and controllers are presented it in Table 1. Both motors have same specifications and applied for SVPWM control technique. The drives is simulated based on three different speed reference operations which are 2000RPM, 1000RPM and 100RPM at $t=0 \mathrm{~s}$. When $\mathrm{t}=0.2 \mathrm{~s}$, the PMSM is instructed to reverse the operation speed to -2000RPM, -1000RPM and -100RPM respectively. At $\mathrm{t}=0.7 \mathrm{~s}$, the PMSM is instructed to move forward again. A detailed speed reference for forward-reversal is explained and illustrated in Figure 3. The transient responses of the drives are shown in Figure 4 to Figure 7 for different speed and load applied.

Figure 6 shows the value of speed drop during load disturbance for various sizes of loads. From this figure, it can be concluded that, the speed drop for large and medium speed references are almost similar for the same load applied. This part presents the speed responses behavior of dual permanent magnet synchronous motor (PMSM) driven by mean and differential torque control technique based on three-leg inverter. This technique shows good speed regulation for wide range of speed either with no load or variation of load.

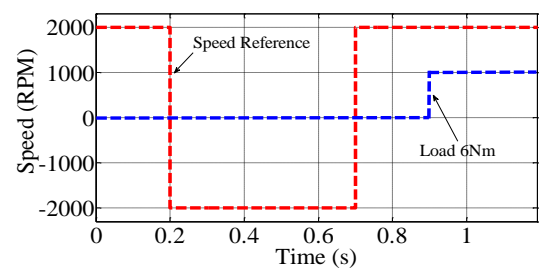

Figure 3. Speed reference of dual-PMSM drives for large speed reference (2000-RPM)

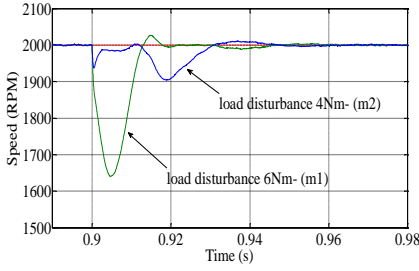

Figure 4(a). Speed responses for $\mathrm{m} 1$ and $\mathrm{m} 2$ at $2000 \mathrm{RPM}$ during load disturbance test

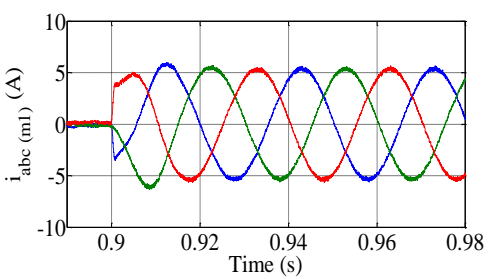

Figure 4(d). Three-phase current for $\mathrm{m} 1$ during load disturbance

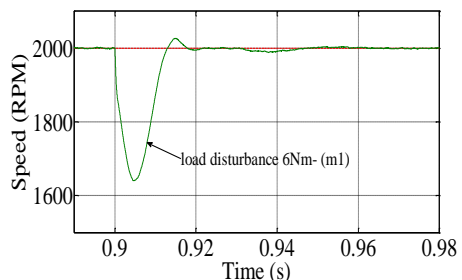

Figure 4(b). Speed response for $\mathrm{m} 1$

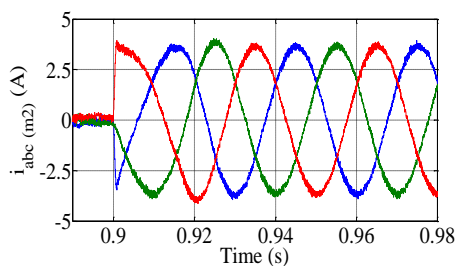

Figure 4(f). Three-phase current for $\mathrm{m} 2$ during load disturbance

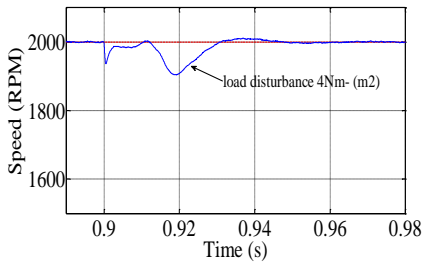

Figure 4(c). Speed response for $\mathrm{m} 2$

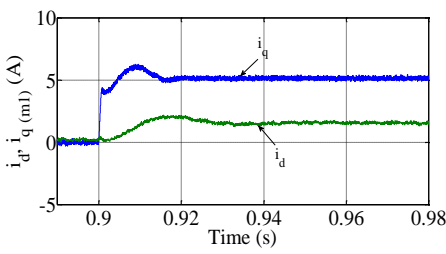

Figure 4(g). Direct and quadrature currents, (id and iq) for $\mathrm{m} 1$ during load disturbance

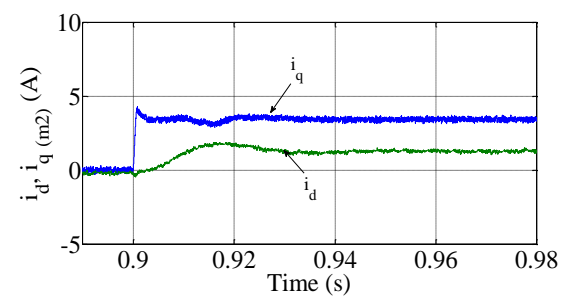

Figure 4(g). Direct and quadrature currents for $\mathrm{m} 2$ during load disturbance

Figure 4. Load disturbance at 2000 RPM 


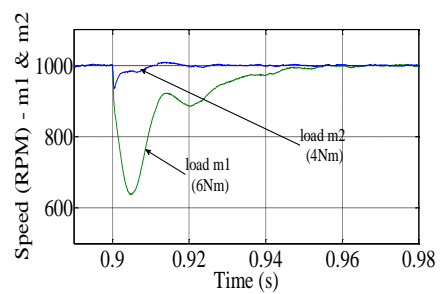

Figure 5(a). Speed responses for $\mathrm{m} 1$ and $\mathrm{m} 2$ at $1000 \mathrm{RPM}$ during load disturbance test

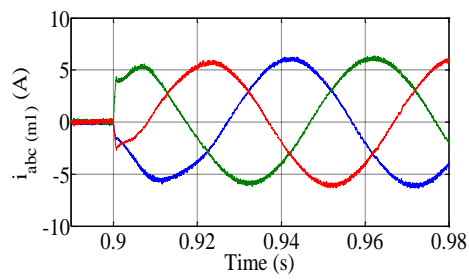

Figure 5(d). Three-phase current for $\mathrm{m} 1$ during load disturbance

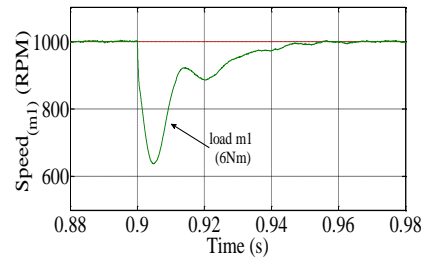

Figure 5(b). Speed response for $\mathrm{m} 1$ Figure 5(c). Speed response for

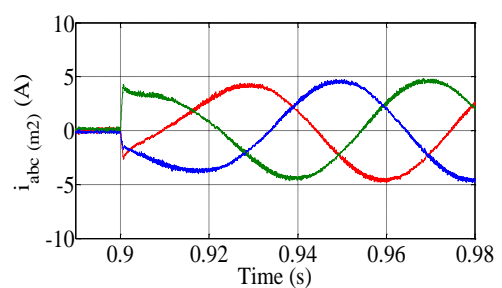

Figure 5(e). Three-phase current for $\mathrm{m} 2$ during load disturbance

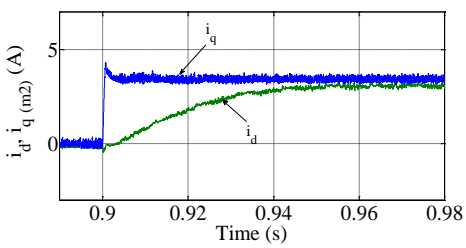

$\mathrm{m} 2$
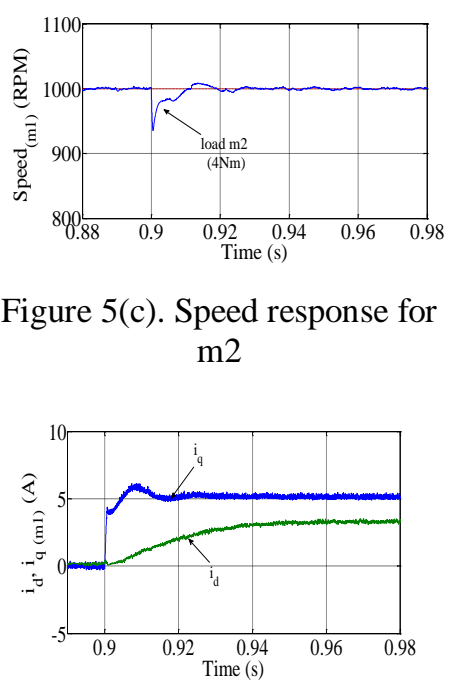

Figure 5(f). Direct and quadrature currents, (id and iq) for $\mathrm{m} 1$ during load disturbance

Figure 5(g). Direct and quadrature currents for $\mathrm{m} 2$ during load disturbance

Figure 5. Load disturbance at 1000 RPM

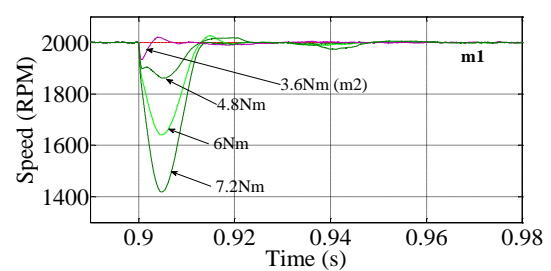

(a)

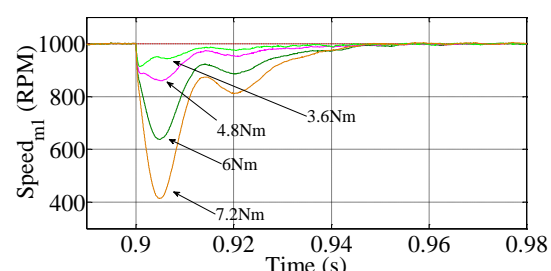

(b)

Figure 6. Speed responses for load variation of PMSM drives for various speed references, (a) Speed responses for load variations at 2000rpm, (b) Speed responses for load variations at 1000rpm

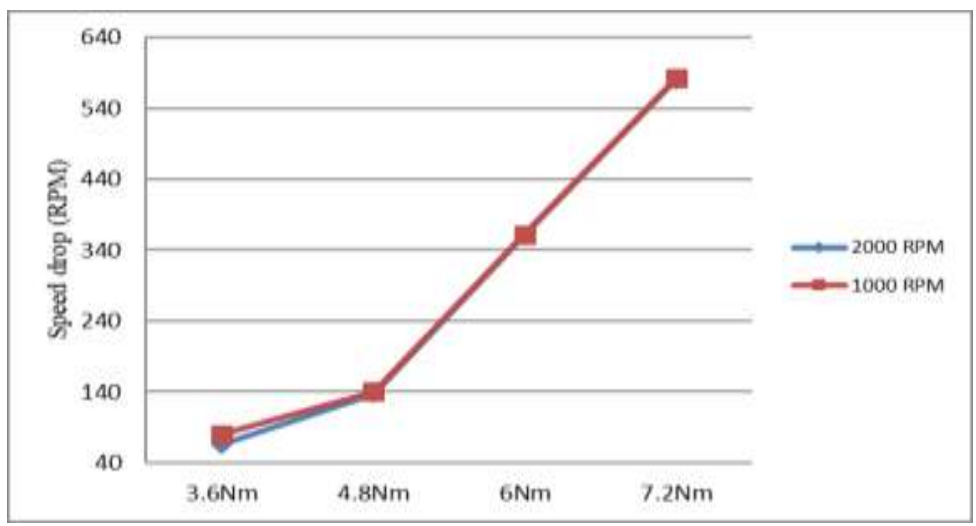

Figure 7. Speed drop versus Load variation for Dual-PMSM drives fed by a single three-leg VSI 


\section{CONCLUSION}

Overall simulation results have shown that the speed responses obtained from the mean-differential control technique are almost similar compared to single motor drives technique. It is should be noted that operation of the drives with variation of load torque become progressively worse as the load torque is equal and higher than the maximum load for dual-PMSM drives using three-leg based on mean and differential control technique. On the other hand, this mean and differential technique has limitation which can't be operated for different speed profiles for both motors at the same time.

\section{ACKNOWLEDGEMENTS}

The author would like to acknowledge "Centre of Robotic \& Industrial Automation" (CERIA), "Centre of Research and Innovation Management" (CRIM), UniversitiTeknikal Malaysia Melaka (UTeM) and Ministry of Higher Education Malaysia(MOHE) for supporting this project.

\section{REFERENCES}

[1] Wang, X., Wang, Z. and Xu, Z., "A hybrid direct torque control scheme for dual three-phase PMSM drives with improved operation performance". IEEE Transactions on Power Electronics, 2018, vol.34, no.2, pp.1622-1634.

[2] An, Q., Liu, J., Peng, Z., Sun, L. and Sun, L., "Dual-space vector control of open-end winding permanent magnet synchronous motor drive fed by dual inverter", IEEE Transactions on Power Electronics, 2016, vol.31, no.12, pp.8329-8342.

[3] Diab, Mohamed S., Ahmed M. Massoud, Shehab Ahmed, and Barry W. Williams. "Dual modular multilevel converter with shared capacitor sub-module for MV open-end stator winding machine drives." The Journal of Engineering 2019, no. 17,pp. 4401-4405.

[4] Riedemann, Javier, et al. "Open-end winding induction machine fed by a dual-output indirect matrix converter." IEEE Transactions on Industrial Electronics, 2016, vol. 63, no. 7, pp.4118-4128.

[5] Wu, Jinglai, et al. "Efficiency comparison of electric vehicles powertrains with dual motor and single motor input." Mechanism and Machine Theory 128 (2018): pp 569-585

[6] Ruan, Jiageng, and Qiang Song. "A novel dual-motor two-speed direct drive battery electric vehicle drivetrain." IEEE Access 7 (2019): 54330-54342.

[7] Mhammed Hasoun, et al. "Field oriented control based on a 24-sector vector space decomposition for dual threephase PMSM applied on electric ship propulsion", International Journal of Power Electronics and Drive System, IJPEDs, (Sept. 2020) vol 11, no.3 pp 1175-1187.

[8] Chebel Ahlem, Benretem A, Dobrev I, Barkati Barkati, "Comparative study of two control strategies proportional integral and fuzzy logic for the control of a doubly fed induction generator dedicated to a wind application" International Journal of Power Electronics and Drive System, IJPEDs, (March. 2020) vol 11, no.1 pp 263-274

[9] Li, Z. \& Fengchun, S. Year. "Torque control of dual induction motors independent drive for tracked vehicle". In: 2008 10th Intl. Conf. on Control, Automation, Robotics and Vision, 2009. IEEE, pp 68-72.

[10] Bidart, D., Pietrzak-David, M., Maussion, P. \& Fadel, M. Year. "Mono inverter dual parallel PMSM-structure and control strategy". In: 34th Industrial Electronics Annual Conference, 2008, IECON 2008, 2009. IEEE, pp 268-273.

[11] Wang, J., Wang, Y., Wang, Z., Yang, J., Pei, Y. \& Dong, Q. Year. "Comparative Study of Vector Control Schemes for Parallel-Connected Induction Motors". In: Power Electronics Specialist Conference, 2005, PESC 05, IEEE 36th, 2006. IEEE, pp 1264-1270.

[12] Mohktari, H. \& Alizadeh, A. Year. "A new multi-machine control system based on Direct Torque Control algorithm". In: The 7th International Conference on Power Electronics, EXCO 2007, 2008. IEEE, pp 1103-1108.

[13] Kelecy, P. \& Lorenz, R. Year. Control methodology for single stator, "Dual-rotor induction motor drives for electric vehicles”. In: Power Electronics Specialist Conference, 1995, PESC'95, 1995. IEEE, pp 572-578.

[14] Del Pizzo, A., Iannuzzi, D. \& Spina, I. Year. "High performance control technique for unbalanced operations of single-vsi dual-PM brushles motor drives". In: 2010 IEEE International Symposium on Industrial Electronics (ISIE), 2010. IEEE, 1302-1307.

[15] Acampa, M., Del Pizzo, A. \& Iannuzzi, D. Year. "Optimized control technique of single inverter dual motor ACbrushless drives". In: Universities Power Engineering Conference, 2008, UPEC 2008, IEEE, pp 1-6.

[16] A.Del Pizzo, D. I., I.Spina 2009. "Optimum Torque/Current control of dual PMSM single VSI Drive". 15th International Symposium on Power Electronics-Ee 2009, Novi Sad, Republic of Srbia.

[17] A. Rajasekhar, R. K. Jatoth, A. Abraham, and V. Snasel, "A novel hybrid ABF-PSO algorithm based tuning of optimal FOPI speed controller for PMSM drive," in The 12th International Conference on Carpathian Control (ICCC2011), Velke Karlovice 2011, pp. 320-325.

[18] P. Pillay and R. Krishnan, "Modeling, simulation, and analysis of permanent-magnet motor drives. I. The permanentmagnet synchronous motor drive," Industry Applications, IEEE Transactions on, vol. 25, pp. 265-273, 1989.

[19] Yeam, Tae-Il, and Dong-Choon Lee. "Speed control of single inverter dual PMSM drives using sliding mode control.", 2019 IEEE Vehicle Power and Propulsion Conference (VPPC), pp. 1-6.

[20] Lazi, J.M., Ibrahim, Z., Talib, M.H., Jidin, A. and Sutikno, T., "Speed and Position Estimator of Dual-PMSM for Independent Control Drives using Five-Leg Inverter", International Journal of Power Electronics and Drive Systems, 2017, vol.8, no.2, p.612. 
[21] Yun, Chul, and Woo-Hyen Kwon. "The resonance characteristic analysis for speed control of parallel connected dual SPMSMs fed by a single inverter." The Transactions of the Korean Institute of Electrical Engineers, 2017, vol.66, no. 4, pp. 643-650.

[22] Yun, Chul, Woo-Hyen Kwon, and Nae-Soo Cho. "The Vibration Suppression using Reactive Power Compensator for Speed Control of Parallel Connected Dual Fan Motors fed by a Single Inverter." The Transactions of the Korean Institute of Electrical Engineers, 2016, vol. 65, no. 12, pp 2008-2013.

[23] Cervone, A., L. P. Di Noia, R. Rizzo, I. Spina, and R. Miceli. "A Constrained Optimal Model Predictive Control for Mono Inverter Dual Parallel PMSM Drives.", 7th International Conference on Renewable Energy Research and Applications (ICRERA), 2018, pp. 1501-1507

[24] Cervone, A., L. P. Di Noia, R. Rizzo, and I. Spina. "A novel current references limitation strategy in mono-inverter dual PMSM Drives." In 2018 XIII International Conference on Electrical Machines (ICEM), pp. 1353-1359. IEEE, 2018.

[25] G. Brando, A. Cervone, A. Del Pizzo and I. Spina, "Sensorless control of single-inverter dual-motor ac brushless drives," IEEE International Symposium on Sensorless Control for Electrical Drives (SLED), Catania, 2017, pp. 173180.

Appendix

Table 1. Motor Specifications

\begin{tabular}{lll}
\hline No & Motor Specifications & Value \\
\hline 1 & Resistance (R) & $4.33 \Omega$ \\
2 & Inductance (L) & $17.6 \mathrm{mH}$ \\
3 & Torque Constant & $1.654 \mathrm{Nm}$ \\
4 & Max. Torque & $6 \mathrm{Nm}$ \\
5 & Pole pair (P) & 4 \\
6 & Flux linkage & 0.1949 \\
7 & Rated speed & $2000 \mathrm{rpm}$ \\
8 & Current Cont. Stall & $5.7 \mathrm{~A}_{\text {peak }}$ \\
9 & Inertia & $0.0006329 \mathrm{kgm}^{2}$ \\
10 & DC link Voltage & $300 \mathrm{~V}$ \\
\hline
\end{tabular}

\section{BIOGRAPHIES OF AUTHORS}
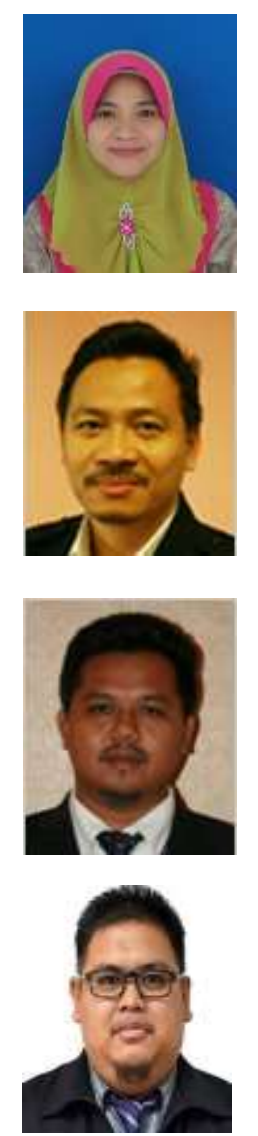

Jurifa binti Mat Lazi received her Bachelor's degree in Electrical Engineering from Universiti Teknologi Malaysia in 2001. She then obtained her Master of Science degree in Electrical Power Engineering from University Universiti Teknologi Malaysia, in 2003. She received her Ph.D degree from University Universiti Teknikal Malaysia Melaka in 2016. She has served as an academic staff at Universiti Teknikal Malaysia Melaka (UTeM) since 2001 and she is currently a senior lecturer at UTeM. Her research interests include Machine Drives especially in Sensorless and PMSM drives, Power Electronics and Power System.

Zulkifilie Ibrahim was born in 1966 in Malaysia. He received his B.Eng. degree from the University of Technology (UTM), Malaysia in 1989 and his PhD degree from the Liverpool John Moores University, UK in 1999. He is currently a Professor at Universiti Teknikal Malaysia Melaka (UTeM), Malaysia. His main research interests are related to power Eectronics, fuzzy logic control, embedded system design and electric motor drives

Md Hairul Nizam Talib was born in Malaysia, in 1976. He received his B.S. in Electrical Engineering from the Universiti Teknologi Malaysia (UTM), Johor, Malaysia, in 1999, M.S. in Electrical Engineering from the University of Nottingham, Nottingham, UK, in 2005 and $\mathrm{PhD}$ from the Universiti Teknikal Malaysia Melaka (UTeM), Malaysia in 2016. He is currently a senior lecturer at UTeM. His main research interests include power electronics, fuzzy logic control and motor drives.

Ahmad Shukri Abu Hasim was born in 1979 in Malaysia. He received his Diploma, Bachelor's and Master degree in Electrical Engineering from Universiti Teknologi Mara, Malaysia, in 2000, 2004, and 2008, respectively. While he received his Ph.D at Universiti Teknikal Malaysia Melaka in 2016. He is currently a senior lecturer at Universiti Pertahanan Nasional Malaysia. His main research areas are related to power electronic, drive systems and renewable energy. 